\title{
2009 ve 2015 İlkokul Matematik Dersi Öğretim Programları ile 2017 İlkokul
}

\section{Matematik Dersi Öğretim Programı Karşılaştırması}

\section{Murat BAȘ}

Öz: Eğitim programları gerek bilimsel, sosyal veya toplumsal yenilikler gerekse farklı etkenlerden dolayı değişime ihtiyaç duymaktadır. $\mathrm{Bu}$ nedenlere bağlı olarak ilkokul matematik dersi öğretim programında da zaman zaman değişime ihtiyaç duyulmuştur. Bu çalışmada 2009 ve 2015 ilkokul matematik dersi öğretim programları ile 2017 ilkokul matematik dersi öğretim programı karşılaştırılmalı olarak değerlendirilmesi amaçlanmıştır. çalışmada nitel araştırma yaklaşımı benimsenmiş olup bir durum çalışması niteliğindedir. Araştırma verilerinin kaynağını ilkokul matematik dersi öğretim program kitapları oluşturduğundan, doküman incelemesi işe koşulmuştur. Çalışmada amaçsal örneklem yöntemlerinden ölçüt örnekleme yöntemi tercih edilmiştir. Araştırma sonucunda 2009 matematik dersi öğretim programı incelendiğinde görülen vizyon başlı̆̆ 2015 ve 2017 programlarında yer almamıştır. 2009 ve 2015 yılı programlarından farklı olarak 2017 matematik dersi programında değerler başlığının kullanıldığı görülmektedir. 2009 yılı matematik dersi öğretim programında toplam 256 kazanım, 2015 yılı matematik dersi öğretim programında toplam 252 ve 2017 yılı matematik dersi öğretim programında ise toplam 229 kazanımın yer aldığı tespit edilmiştir. 2009 yılı programında yer alan 4 temel beceri 2015 yılı programında 6 temel beceri ve 2017 yll programında ise 9 temel beceri olarak tespit edilmiştir. Programlarda öğrenme öğretme süreçlerine ilişkin açıklamalara 2009 y1lı programında 15 madde, 2015 yılı programında 12 madde ve 2017 y1lı programında ise 13 madde olarak yer verildiği saptanmıştır.

\footnotetext{
* Arş. Gör. Murat BAŞ, Ahi Evran Üniversitesi, Eğitim Fakültesi, Temel Eğitim Bölümü, Sınıf Eğitimi Anabilim Dalı, Kırşehir muratbas@ ahievran.edu.tr Orcid ID: 0000-0003-3616-769X
} 
YYÜ Eğitim Fakültesi Dergisi (YYU Journal Of EducationFaculty),2017; 14(1):1219-1258, http://efdergi.yyu.edu.tr http://dx.doi.org/10.23891/efdyyu.2017.44

ISSN:1305-020

Anahtar Sözcükler: Matematik dersi öğretim programı, hedefler, içerik, eğitim durumları, değerlendirme.

\section{Comparison of 2009, 2015 Primary School Mathematics Curricula and 2017 Primary School Mathematics Curriculum}

Abstract: Primary school mathematics curricula needed some changes time to time. In this study, comparative examination of 2009, 2015 and 2017 primary school mathematics curricula was aimed. Within the context of its aim, qualitative research approach has been applied, and the study is a case study from qualitative research models. In this study, the data source stated as primary school mathematics curricula' books hence, the document examination was required. In the study, criterion sampling method was chosen from object based sampling methods. As a result of this study, it is observed that 2009 primary school mathematics curriculum has a vision, on the other hand, 2015 and 2017 primary school mathematics curricula, the vision is not included. While in 2009 and 2015 mathematics curricula the values caption was not included, the caption of values was included in 2017 mathematics curriculum. In the 2009 mathematics curriculum there were 256 learning outcome; in 2015, there were 252 learning outcome and in 2017, there were 229 learning outcome observed at total. It was determined that the skills score which was 4 in 2009, was 6 in 2015 and 9 in 2017. Explanations about the teaching and learning processes in the 2009 mathematics curriculum were listed as in 15 items, in the 2015 mathematics curriculum as 12 items and the 2017 mathematics curriculum, they are listed as in 13 items.

Key Words: mathematics curricula, objective, content, educational attaintment, evaluation 


\section{Giriş}

Matematik nedir? Matematik tek bir anlam ve tek bir değer ile ifade edilemez çünkü matematik "matematikçinin özgür iradesiyle birbiri ile tutarlı olması gereken tanımlardan ve önermelerden çıkardığg sonuç sistemidir (Courant, Robbins \& Stewart 1996:5). Benzer bir tanım ise (Burton, 1990 akt. Akman, 2002) tarafından "matematik birbirleri ile ilişkili olan özellikler bütünüdür” şeklinde yapılmıştır. Hızla değişen ve değişimle beraber gelişen dünyada zaman değiştikçe yeni yeni problemler ortaya çıkmaktadır. Bunlarla bağlantılı olarak da matematiğin başka yönleri ve yeni karakteristik özellikleri ortaya çıkmakta ve önceden "tanım" olarak söylenmekte olan ifadelerin de değişime uğraması gerekmektedir (Nasibov ve Kaçar, 2005). Buna örnek olarak Türk Dil Kurumu'nun iki ayrı dönemde yapmış olduğu tanımlar gösterilebilir. TDK' ye göre (1983) matematik, "biçim, sayı ve çoklukların yapıların, özelliklerini ve aralarındaki ilişkileri usbilim (mantık) yoluyla inceleyen ve sayı bilgisi (aritmetik), cebir, uzam bilim (geometri) gibi dallara ayrılan bilim dalı" (Akt. Umay, 2002:275) olarak tanımlanırken yine TDK'ye göre (2017) matematik, “aritmetik, cebir, geometri gibi sayı ve ölçü temeline dayanarak niceliklerin özelliklerini inceleyen bilimlerin ortak adı olarak tanımlanmaktadır. İki ayrı tanımdan yola çıkarak, ilk tanımın matematik disiplinini kendi içinde ayrıştırarak tanımlamaya çalışırken ikinci tanımda farklı disiplinlerin odağına alınmış ve özelikleri bilinen bir matematik görülmektedir.

Dünyadaki bu değişime uyum sağlayabilmek için matematik de kendi içinde yenilenmektedir. $\mathrm{Bu}$ değişim matematiğin bireye formal olarak öğretildiğgi ilk yerde de kendini göstermek zorunda kalacaktır (Cooke, 2011; Trautwein, Koller, Schmitz \& Baumert, 2002). Bu yüzden matematik dersi öğretim programlarına da bu değişimlerden doğan yeniliklerin yansıtılması gerekmektedir. Bu bağlamda eğitim programları da gerek bilimsel, sosyal veya toplumsal yenilikler gerekse farklı etkenlerden dolayı değişime ihtiyaç duymaktadır. Örneğin, Howson, Keitel \& Kilpatrick (2008:6) matematik öğretim 
programının yenilenmesinde rol oynayan "toplumsal ve politik, yeniliğin getireceği teşvikler, eğiticiler ve matematiksel” olmak üzere dört farklı etken olduğunu söylemektedirler. $\mathrm{Bu}$ nedenle zaman içerisinde değişimlere bağlı olarak öğretim programlarının da değişimi zorunlu kılınmaktadır (Tay, 2017). Bu nedenlere bağlı olarak da ilkokul matematik dersi öğretim programında da zaman zaman değişime ihtiyaç duyulmuştur.

Türkiye'de Cumhuriyet'in ilanıyla beraber 1924 yılında çıkarılan Öğretim Birliği Yasası ile tüm öğretim kurumları Millî Eğitim Bakanlığı bünyesi altında toplanmış ve il Millî eğitim müdürlüklerinin desteği ile başlayan program geliştirme çalışmaları daha sonra Millî Eğitim Bakanlığı merkez örgütünde devam etmiştir (Demirel, 1992). Araştırmacılar iyi bir müfredat geliştirmenin en etkili yollarından birinin geçmiş müfredatları incelemek olduğunu belirtirken, bu yolla geçmişten geleceğe bir yol haritasının çizilebileceği görüşünü savunmuştur (Özmantar, 2017; Lester, 2013; Schoenfeld, 2004). Cumhuriyet tarihi boyunca 1924, 1926, 1936, 1948, 1968, 1983, 1990, 1998, 2005, 2015 (Özmantar ve Öztürk, 2017; Ergün, Özmantar, Bay ve Ağaç, 2015) ve 2017 yıllarında matematik öğretim programının değiştiği görülmektedir.

Cumhuriyet'in ilanından hemen sonra, yürürlüğe giren 1924 öğretim programından sonra Türkiye'ye davet edilen John Dewey'in hazırladığı rapor doğrultusunda gözden geçirilerek 1926'da ilkokul öğretim programı olarak on yıl boyunca uygulamada kalmıştır ve 1936 yılında yeniden şekillenmiştir. 1948 öğretim programı (Milli Eğitim Bakanlığı, 1948) Cumhuriyet tarihimiz boyunca en uzun süre kullanılan bir öğretim programıdır. 1952 yılında yurdumuza gelerek köy okullarında incelemeler yapan Wofford'un hazırladığı raporla 1968 programları daha sistematik bir yaklaşımla yapılmaya başlanmıştır. Bu bağlamda Millî Eğitim Bakanlığı bünyesinde oluşturulan dokuz kişilik bir ekip ile "amaç, davranış, işleyiş ve değerlendirme" boyutlarını kapsayacak şekilde program modeli oluşturulmuş ve buna uygun programlar yapılması beklenmekteydi (Demirel, 1992). Bir model odağında hazırlanması 
beklenen programların birbirinden hem bağımsız hazırlanması hem de ortak bir model etrafında yapılıyor olması programın dönemin sosyo-kültürel ihtiyaçlarını bölgesel farklılıkları gözeterek karşılamasında (MEB, 1968) olumlu olacağı söylenebilir. Hazırlanan programlar incelendiğinde MEB bünyesinde kurulan ekibin beklentilerini karşılayan tek program örneği matematik programı olduğu için 1983 yılında bu program ilk model olarak denenmiştir (Demirel, 1992). 1990'lı yıllarda öğretim programı geliştirme çabaları, 8 yıllık eğitim kapsamında hazırlanmıştır. 1990 yılı programında konuların ve birimlerin dağılımı bu 8 yıllık sürekli eğitim temel alınarak ayarlanmıştır. 1997 yılında 8 yıllık eğitimin zorunlu eğitim olarak yasalaşmasıyla sekiz yıllık eğitimin tümünü kapsayan yeni bir matematik dersi öğretim programı geliştirilmiştir. 1990 ve 1998 öğretim programının içeriği ve yaklaşımları açısından 1983 öğretim programıyla büyük benzerlikleri vardır (MEB, 1990; Vural, 1998; MEB, 1983). 1990'lı yıllarda geliştirilen öğretim programı eleştirilerin hedefi olmuştur. Eleştirilerin odağında ise bu programların en son bilimsel gelişmelerin içeriğine ve öğretim yaklaşımlarına sahip olmaması yer almaktadır (Demirel, 1992). Bu eleştirileri dikkate alarak, yeni öğretim programı geliştirme çalışmaları 2000'li yılların başında bir ivme kazanmıştır. 2004 yılında yeni bir öğretim programı geliştirilmiş ve bir yıl süren pilot uygulamanın ardından 2005 yılında ülke çapında yürürlüğe girmiştir (Alak ve Nalçacı, 2013). Bu öğretim programı 2015 yılında hazırlanan son öğretim programın uygulanması ile yürürlükten kaldırılmış ve $4+4+4$ olarak düzenlenmiş parçalanmış temel zorunlu eğitim getirilmiştir. $\mathrm{O}$ dönem 2015 öğretim programı, ilköğretimin 4 yıllık bir dönem olarak düzenlendiği ilk ve tek öğretim programı olarak görülmektedir.

Matematik dersi programı değerlendirmesi odağa alınarak son yıllarda Türkiye’ de yapılan çalışmalar incelendiğinde çalışmaların; değerlendirme boyutu ile (Arseven, Kontaş ve Arseven, 2014; Toptaş, 2011; Orbeyi ve Güven, 2008), beceriler boyutu ile (Demir ve Vural, 2017; Özmantar ve Öztürk, 2017; Güneş ve Uygun, 2016), ders kitapları boyutu ile (Bulut, 
Boz ve Yavuz, 2016; Sevimli ve Kul, 2015), öğrenme öğretme süreci boyutuyla (Bekdemir ve Baş, 2017; Baş, 2016; Dinç-Artut, ve Tarım, 2016; Ersoy ve Öksüz, 2016; Kurnaz ve Kutlu, 2016; Baş, 2015; Güngör ve Çavuş, 2015; Şimşek ve Nihat, 2015; Hannula, 2014; Işı1k ve Kar, 2011; Peker ve Halat, 2008), öğretmen ve öğrenci görüşleri çerçevesinde (Dağdelen ve Ünal, 2017; İskenderoğlu ve Uzuner 2017; Özdemir, Bayraktar ve Yılmaz, 2017; Bayraktar ve diğerleri, 2016; Çakır ve Kılınç 2016; Uygun, Gökkurt ve Neslihan, 2016; Yurtbakan, İskenderoğlu ve Sesli, 2016; Gökkurt, Soylu ve Demir, 2015; Öksüz, 2015; Gündoğdu ve diğerleri, 2012; Duru ve Korkmaz, 2010), farklı anlayışlar ve genel özellikler çerçevesinde (Gözütok, 2003; Umay, Çıkla ve Duatepe, 2006; Erdoğan, Hamurcu ve Yeşiloğlu, 2017; Öksüz, 2015; Özmantar, 2017; Sezgin Memnun, 2013; Özmantar ve Öztürk, 2016; Erbilgin, 2014; Batd1, 2014; Üçüncü ve Tertemiz, 2012; Özdemir, 2009; Peker, 2009; Tertemiz, 2003) yapıldığı görülmektedir.

$\mathrm{Bu}$ araştırmada Bloom'un programın ögelerine dayalı öğretim programı değerlendirmesi temel alınmış ve buna bağlı olarak hedefler, üniteler, eğitim durumu ve değerlendirme boyutları (Sönmez ve Alacapınar, 2015) ile programın vizyonu ve program yaklaşımı da değerlendirmeye dâhil edilerek 2009, 2015 ve 2017 ilkokul matematik dersi öğretim programları karşılaştırmalı olarak değerlendirilmiştir. Bu bağlamda, alan yazında yer alan çalışmalar incelendiğinde bu kadar kapsamlı bir matematik dersi program değerlendirmesinin yapılmadığı görülmektedir. Ayrıca, alan yazında 2017 ilkokul matematik dersi programına yönelik hiçbir çalışma yer almadığından bu çalışmanın alan yazına önemli ölçüde katkı sağlayacağı ve ileride yapılacak program değerlendirme çalışmalarına kaynaklık edeceği düşünülmektedir.

Araştırmanın amacı: Bu çalışmada 2009, 2015 ve 2017 ilkokul matematik dersi öğretim programlarının karşılaştırmalı olarak değerlendirilmesi amaçlanmıştır. Bu amaç kapsamında aşağıdaki sorulara yanıt aranmıştır: 
1. 2009, 2015 ve 2017 yılı programlarında vizyona yer verilmiş midir?

2. 2009, 2015 ve 2017 y1lı programlarında program yaklaşımına yer verilmiş midir?

3. 2009, 2015 ve 2017 yılı programlarında hedefler boyutu belirtilmiş midir?

3.1. 2009, 2015 ve 2017 yılı programlarında hedefler belirtilmiş midir?

3.2. 2009, 2015 ve 2017 yılı programlarında kazanımlara nasıl yer verilmiştir?

4. 2009, 2015 ve 2017 yılı programlarında içerik boyutu nasıl verilmiştir?

4.1. 2009, 2015 ve 2017 yılı programlarında öğrenme alanlarına, ünitelere, becerilere, değerlere, aradisiplinlere yer verilmiş midir?

5. 2009, 2015 ve 2017 yılı programlarında eğitim durumları boyutu belirtilmiş midir?

5.1. 2009, 2015 ve 2017 y1lı programlarında öğrenme öğretme süreçlerine, etkinlik örneklerine ilişkin açıklamalara, kazanımlar ve etkinlikler için açıklamalara ve ders saatlerine ilişkin açıklamalara yer verilmiş midir?

6. 2009, 2015 ve 2017 yılı programlarında değerlendirme boyutu belirtilmiş midir?

\section{Yöntem}

Çalışmanın amacı doğrultusunda bu çalışmada nitel araştırma yaklaşımı benimsenmiş, 2009, 2015 ve 2017 yılı ilkokul matematik dersi öğretim programları karşılaştırmalı olarak betimlenmiştir. Fraenkel \& Wallen’ e göre (1996) nitel araştırmalar belirli bir birey, grup veya koşul hakkında detaylı bir çerçeve ortaya koyar. $\mathrm{Bu}$ çalışma, nitel araştırma modellerinden durum çalışması niteliğindedir. Nitel araştırmalar, araştırılacak konunun ya da konuların kendi ortamındaki koşullarını veya durumlarını tespit etmek amacı ile yapılmaktadır. Nitel araştırmalar yapılırken veri toplama yöntemi olarak yaygın olarak görüşme, gözlem ve doküman incelemesi teknikleri kullanılmaktadır (Ekiz, 2003; Kuş, 2003; Yıldırım ve Şimşek, 2011). Bu çalışmada, araştırma verilerinin kaynağını ilkokul matematik dersi öğretim programı kitapları oluşturduğundan, veri toplama yöntemi olarak doküman incelemesi işe koşulmuştur. Çalışma betimsel bir durum çalışması olarak tasarlanmıştır. 
Durum çalışması, doğal ortamlarında tek veya küçük bir grubun sosyal olgusunu anlamayı amaçlayan bir araştırma stratejisidir. Durum çalışmasında yapılmak istenen ise, ele alınan örneğin kapsamlı bir şekilde betimlenmesinin amaçlanmasıdır (Bloor \& Wood, 2006). Bu araştırmada, 2009, 2015 ve 2017 ilkokul matematik dersi öğretim programları karşılaştırmalı olarak detaylı bir şekilde betimlenmeye çalışılmıştır.

Verilerin Kaynağı: Çalışmada amaçsal örneklem yöntemlerinden ölçüt örnekleme yöntemi tercih edilmiştir. Büyüköztürk, Kılıç Çakmak, Akgün, Karadeniz ve Demirel’e göre (2012) araştırmada gözlem birimlerini belirgin niteliklere sahip kişi, olay, nesne ya da durumları oluşturabilir. $\mathrm{Bu}$ bağlamda seçilecek örneklem için belirlenen ölçüte karşılık gelebilen nesne, olay, belge vb. örnekleme alınır. Bu amaçla araştırmada veri kaynağını Millî Eğitim Bakanlığı tarafından onaylanmış 2009 ilkokul matematik dersi öğretim program kitabı, 2015 ilkokul matematik dersi öğretim program kitabı ile 2017 matematik dersi öğretim program kitabı oluşturmaktadır. Ölçüt olarak ilkokul matematik dersi programı belirlendiği için 2017 matematik dersi öğretim program incelenirken program sadece ilkokul boyutu ile ele alınmıştır.

Süreç: Araştırmada veri toplama yöntemi olarak doküman incelemesi yöntemi kullanılarak bulgular ortaya çıkarılmıştır. Forster (1995)'e göre doküman analizi (incelemesi), kaynaklara ulaşma, ulaşılan kaynakların doğruluğunu kontrol etme, kaynakları anlama veriyi analiz etme ve veriyi kullanma boyutları ile beş boyutta gerçekleşmektedir (Akt. Yıldırım ve Şimşek, 2011). Yapılan çalışmanın transfer edilebilirliğini artırmak için çalışmada detaylı betimlemelere yer verilmiştir. Bu bağlamda; verilerin toplanma süreci veri kaynağının özellikleri, nasıl seçildikleri, veri analiz süreci ve araştırmanın sınırlılıkları ayrıntılarıyla araştırmada sunulmuştur. Bu şekilde araştırmanın transfer edilebilirliğine katkı sunulmaya çalışılmıştır (Creswell \& Miller, 2000). Çalışmada izlenen adımlar aşağıda sıralanmıştır: 
Birinci adım olarak dokümanlara ulaşılmıştır. Bogdan \& Biklen (1992) ve Goetz \& LeCompte (1984)'e göre eğitim ile ilgili çalışmalarda; ders kitapları, program yönergeleri, okul içi ve dışı yazışmalar, öğrenci kayıtları, toplantı tutanakları, öğrenci rehberlik kayıt ve dosyaları, öğrenci ve öğretmen el kitapları, ders ve ünite planları, öğretmen dosyaları, öğrenci portföy dosyaları, eğitim ile ilgili resmi belgeler vb. veri kaynağı olarak kullanılabilmektedir (Akt. Yıldırım ve Şimşek, 2011). Bu çerçevede çalışmanın verilerini 2009, 2015 ve 2017 ilkokul matematik dersi öğretim program kitapları oluşturmuştur. Belgeler, Talim ve Terbiye Kurulu ağ sayfasından elde edilmiştir.

İkinci adımda belgelerin orijinalliği test edilmiştir. Bowen (2009)'e göre belgelerin çalışmacıdan bağımsız olarak kayda alınmış görüntü, ses ve metinleri içermesi gerekmektedir. Bu bağlamda Talim ve Terbiye Kurulu ăg sayfasından alınan program kitapları olduğu gibi araştırmada kullanılmıştır.

Üçüncü adımı dokümanları anlama oluşturmaktadır. $\mathrm{Bu}$ adımda dokümanların birbirleriyle karşılaştırmalı olarak belirli bir sistem içinde olması ve çözümlenmesi gerekmektedir (Yıldırım ve Şimşek, 2011). Bu amaçla programlar tek tek ve birbirleriyle karşılaştırmalı olarak araştırmanın amacı doğrultusunda oluşturulan alt problemlere göre incelenmiştir.

Dördüncü adım olarak ise veri analizine geçilmiştir. Yapılan veri analizinde aşağıdaki aşamalar takip edilmiştir:

a. Analize konu olan veriden örneklem oluşturma: Örneklem amaçsal örnekleme yöntemlerinden ölçüt örnekleme ile oluşturulmuştur.

b. Kategorileri geliştirme: Kategorilerin seçiminde, kategoriler önceden saptanmamıştır. Mesaj ögeleri ele alınıp gözden geçirildikçe açık yaklaşım tercih edilerek kategoriler oluşturulmuştur (Bilgin, 2014). Yani, analiz birimlerinin hangi özelliklere sahip olduğu, program kitapları tekrar tekrar incelenerek saptanmıştır. Araştırmacı ve bağımsız bir 
araştırmacı ayrı ayrı kategori oluşturmuş, araştırmacıların oluşturduğu analiz birimlerine ait kategorilerden tesadüfi belirlenen 3 birim üzerinde kategoriler kendi kategorileriyle karşılaştırılmış ve karşılaştırmalarda görüş birliği ve görüş ayrılığı sayıları tespit edilerek kategorilerin güvenirliği Miles \& Huberman'ın (1994) formülü (Güvenirlik=görüş birliği/görüş birliğii+görüş ayrılığ 1 ) kullanılarak 0,86 olarak hesaplanmıştır. Elde edilen uyum katsayısı kategorilerin yüksek güvenirlikte kullanılabileceğini göstermektedir.

c. Analiz birimini saptama: Analiz birimini 2009, 2015 ve 2017 ilkokul matematik dersi öğretim programlarının; vizyon, program yaklaşımı, hedefler, içerik, eğitim durumları ve değerlendirme boyutları oluşturmuştur. Araştırmada Bloom'un programın ögelerine dayalı öğretim programı değerlendirmesi temel alınmış ve bu bağlamda amaçlar, üniteler, eğitim durumu ve değerlendirme boyutları (Sönmez ve Alacapınar, 2015) çalışmanın analiz birimini oluşturmuştur.

d. Sayısallaştırma: Araştırmacı tarafından oluşturulan kategoriler aracılığı ile verileri anlama ve verilerin analizi adımlarına geçilmiş, böylece bu adımı, oluşturulan kategorilerin frekanslarının nicel olarak belirlenmesi oluşturmuştur. Bu adımda ilk olarak her program tek tek incelenerek analiz birimlerinin programlarda var olup olmadığı saptanmış, böylece frekanslar belirlenmiştir. Elde edilen veriler tablolar ile sunulmuş ve çalışmayı yürüten araştırmacı tarafından yapılan yorumları desteklemek için programlardan örnek teşkil edecek alıntılara yer verilmiştir.

\section{Bulgular}

2009, 2015 ve 2017 yıllarındaki programlarda vizyon

Tablo 1. 2009, 2015 ve 2017 yıllarındaki programlarda vizyon

$20092015 \quad 2017$

Problem çözebilen

$>$ Çözümlerini ve düşüncelerini paylaşabilen

> Ekip çalışması yapabilen

$>$ Matematikte özgüven duyabilen

Matematiğe yönelik olumlu 
tutum geliştiren

2009 matematik dersi öğretim programının bir vizyona sahip olduğu, 2015 ve 2017 programlarında ise vizyona yer verilmediği tespit edilmiştir. 2009 matematik dersi öğretim programında ise ilkokulu tamamlayan bir öğrencinin sahip olması gereken 5 maddeden oluşan özellikler vizyon olarak verilmiştir.

2009, 2015 ve 2017 yıllarındaki programlarda program yaklaşımı

Tablo 2. 2009, 2015 ve 2017 yıllarındaki programlarda program yaklaşımı

\begin{tabular}{|c|c|c|}
\hline 2009 & 2015 & 2017 \\
\hline$>$ Kavramsal yaklaşım & $>--$ & $>\quad--$ \\
\hline$>$ Tematik Yaklaşım & $>$ Tematik Yaklaşım & $>$ Tematik Yaklaşım \\
\hline > Öğrenci Merkezli & $>$ Öğrenci Merkezli & $>$ Öğrenci Merkezli \\
\hline$>$ & $>$ Ünite temelli yaklaşım & $>$ Ünite temelli yaklaşım \\
\hline
\end{tabular}

2009 matematik dersi öğretim programında programın yaklaşımı olarak bir bölüm ayrılmış olup kavramsal yaklaşımın benimsendiği belirtilmiştir. Ancak 2009, 2015 ve 2017 matematik dersi programları incelendiğinde her üç programında aynı zamanda tematik ve öğrenci merkezli yaklaşım anlayışlarını benimsediğini görülmektedir. 2015 ve 2017 programlarında ayrıca ünite temelli bir yaklaşım benimsendiği de tespit edilmiştir.

2015 ve 2017 yılları ilkokul matematik dersi öğretim programlarında "matematik dersi ögretim programlarının genel amaçları" ve "ögrretim programında dĕgerler ĕgitimi” başlıkları altında öğretmenlere yaklaşım konusunda esneklik sunulduğu ifade edilmiştir. Bu bağlamda öğretmenlerin sınırlandırılmayarak hangi yaklaşımın daha faydalı olacağına karar vererek kullanması gerektiği vurgulanmıştır.

2009, 2015 ve 2017 yıllarındaki programlarda hedefler 2009, 2015 ve 2017 yıllarındaki programlarda hedefler

Tablo 3. 2009, 2015 ve 2017 yıllarındaki programlarda hedefler

\begin{tabular}{|c|c|c|}
\hline 2009 & 2015 & 2017 \\
\hline $\begin{array}{l}\text { Türk Millî Eğitimi’nin Genel } \\
\text { Amaçları }\end{array}$ & $>--$ & $D_{--}$ \\
\hline $\begin{array}{l}\text { Matematikte veya diğer } \\
\text { alanlarda ileri bir eğitim } \\
\text { alabilmek için gerekli } \\
\text { matematiksel bilgi ve becerileri } \\
\text { kazanabilecektir. }\end{array}$ & $>--$ & $>--$ \\
\hline
\end{tabular}


Mantıksal tümevarım ve tümden

gelimle ilgili çıkarımlar yapabilecektir.

$>$ Problem çözme stratejileri geliştirebilecek ve bunları günlük hayattaki problemlerin çözümünde kullanabilecektir

> Model kurabilecek, modelleri sözel ve matematiksel ifadelerle ilişkilendirebilecektir.

> Matematiğin gücünü ve ilişkiler ağı içeren yapısını takdir edebilecektir.

$>$ Entelektüel merakı ilerletecek ve geliştirebilecektir

> Matematiğin tarihî gelişimi ve buna paralel olarak insan düşüncesinin gelişmesindeki rolünü ve değerini, diğer alanlardaki kullanımının önemini kavrayabilecektir.
> Matematiksel okuryazarlık becerilerini geliştirebilecek ve etkin bir şekilde kullanabilecektir.

$>$ Matematiğin anlam ve dilini kullanarak insan ile nesneler arasındaki ilişkileri ve nesnelerin birbiri ile ilişkilerini aanlamlandirabilecektir.

> Üstbilişsel bilgi ve becerilerini geliştirebilecek; kendi öğrenme süreçlerini bilinçli biçimde yönetebilecektir.

$>$ Kavramları farklı temsil biçimleri ile ifade edebilecektir. $>-$

Matematiksel kavramları anlayabilecek, bu kavramları günlük hayatta kullanabilecektir.
Matematiksel okuryazarlık becerilerini geliştirebilecek ve etkin bir şekilde kullanabilecektir.

$>$ Matematiğin anlam ve dilini kullanarak insan ile nesneler arasındaki ilişkileri ve nesnelerin birbiri ile ilişkilerini anlamlandirabilecektir.

> Üstbilişsel bilgi ve becerilerini geliştirebilecek; kendi öğrenme süreçlerini bilinçli biçimde yönetebilecektir.

> Kavramları farklı temsil biçimleri ile ifade edebilecektir.

$>$ Matematiğin insanlığın ortak bir değeri olduğunun bilincinde olarak matematiğe değer verecektir

> Matematiksel kavramları anlayabilecek, bu kavramları günlük hayatta kullanabilecektir.

Problem çözme sürecinde kendi düşünce ve akıl yürütmelerini rahatlıkla ifade edebilecek, başkalarının matematiksel akıl yürütmelerinde ki eksiklikleri veya boşlukları görebilecektir.

Problem çözme sürecinde ken duşunce ve akıl yürütmelerin başkalarının matematiksel akıl yürütmelerinde ki eksiklikleri veya boşlukları görebilecektir. edebilecektir

> Matematiksel düşüncelerini mantıklı bir şekilde açıklamak ve paylaşmak için matematiksel terminoloji ve dili doğru kullanabilecektir.

> Tahmin etme ve zihinden işlem yapma becerilerini etkin
- Matematiksel düşüncelerini mantıklı bir şekilde açıklamak ve paylaşmak için matematiksel terminoloji ve dili doğru kullanabilecektir.

$>$ Tahmin etme ve zihinden işlem yapma becerilerini etkin bir
> Matematiksel düşüncelerini mantıklı bir şekilde açıklamak ve paylaşmak için matematiksel terminoloji ve dili doğru kullanabilecektir.

Tahmin etme ve zihinden işlem yapma becerilerini etkin bir 
kullanabilecektir.

Matematiğe yönelik olumlu tutum geliştirebilecek, öz güven duyabilecektir.

Sistemli, dikkatli, sabırlı ve sorumlu olma özelliklerini geliştirebilecektir.

$>$ Araştırma yapma, bilgi üretme ve kullanma gücünü geliştirebilecektir.

$>$ Matematik ve sanat ilişkisini kurabilecek, estetik duygular geliştirebilecektir. şekilde kullanabilecektir.

$>$ Matematiği öğrenmede deneyimleriyle matematiğe yönelik olumlu tutum geliştirerek, matematiksel problemlere özgüvenli bir yaklaşım geliştirecektir.

> Sistemli, dikkatli, sabırlı ve sorumlu olma özelliklerini geliştirebilecektir

$>$ Araştırma yapma, bilgi üretme ve kullanma becerilerini geliştirebilecektir.

> Matematiğin sanat ve estetikle ilişkisini fark edebilecektir. şekilde kullanabilecektir.

$>$ Matematiği öğrenmede deneyimleriyle matematiğe yönelik olumlu tutum geliştirerek, matematiksel problemlere özgüvenli bir yaklaşım geliştirecektir.

> Sistemli, dikkatli, sabırlı ve sorumlu olma özelliklerini geliştirebilecektir.

Araştırma yapma, bilgi üretme ve kullanma becerilerini geliştirebilecektir.

Matematiğin sanat ve estetikle ilişkisini fark edebilecektir.

2009, 2015 ve 2017 matematik dersi öğretim programları incelendiğinde her üç

programda da amaçlar ile ilgili bölümün yer aldığı görülmektedir. 2009 programında 2015 ve 2017 programından farklı olarak “Türk Millî Eğitiminin Amaçlarl” başlığı altında ayrıca bir bölüm oluşturulmuştur. Bununla birlikte 2009 programında programın temel ögeleri bölümü altında oluşturulan matematik eğitiminin genel amaçları alt başlıkla kazandırılmak istenen 15 maddelik matematik eğitiminin genel amaçlarına ayrıca yer verilirken 2015 programında 12 ve 2017 programında ise 13 maddelik amaçlar listesi oluşturulduğu görülmektedir. 2015 ve 2017 programlarındaki 8 amaç cümlesi 2009 programı ile benzerlik gösterirken 2015 programında yer alan bütün amaçlar 2017 programında da kendisine yer bulmuştur.

\section{9, 2015 ve 2017 yıllarındaki programlarda kazanımlar}

Tablo 4. 2009, 2015 ve 2017 yıllarındaki programlarda kazanımlar

\begin{tabular}{cccc}
\hline Sinıf & $\mathbf{2 0 0 9}$ & $\mathbf{2 0 1 5}$ & $\mathbf{2 0 1 7}$ \\
\hline 1. Sinıf & 44 & 45 & 36 \\
2. Sinıf & 59 & 57 & 50 \\
3. Sinıf & 69 & 70 & 72 \\
4. Sinıf & 84 & 80 & 71 \\
\hline Toplam & $\mathbf{2 5 6}$ & $\mathbf{2 5 2}$ & $\mathbf{2 2 9}$ \\
\hline 2009, 2015 ve 2017 programları incelendiğinde 3. sinıf hariç tüm sinıf düzeylerinde
\end{tabular}

kazanımların sayısı 2009 yılından 2017 yılına azaldığı görülmektedir. 3. sınıf düzeyinde kazanım sayısına bakıldığında ise 2009 yılında 69 olan kazanım sayısı, 2015 yılında bir, 2017 yılında ise 2 artırılarak 72 olmuştur. Tablo 4'e bakıldığında ise 1. sınıftan 4. sınıf düzeyine 
YYÜ Ĕ̆itim Fakültesi Dergisi (YYU Journal Of EducationFaculty),2017; 14(1):1219-1258, http://efdergi.yyu.edu.tr http://dx.doi.org/10.23891/efdyyu.2017.44

ISSN:1305-020

kadar kazanım sayıları genel olarak artış göstermektedir. Ancak toplam kazanım sayılarına bakıldığında 2009 ile 2015 programları arasında fazla fark görülmese de 2009 yılında 256, 2015 yılında 252 olan kazanım sayısı 2017 yılında 229’a kadar düşürülmüsstür.

\section{9, 2015 ve 2017 yıllarındaki programlarda içerik}

2009, 2015 ve 2017 yıllarındaki programlarda öğrenme alanları

Tablo 5. 2009, 2015 ve 2017 yıllarındaki programlarda ögrenme alanlart

\begin{tabular}{|c|c|c|}
\hline 2009 & 2015 & 2017 \\
\hline$>$ Sayılar & $>$ Sayılar ve işlemler & $>\quad$ Sayılar ve işlemler \\
\hline$>$ Geometri & $>$ Geometri & $>$ Geometri \\
\hline$>$ Ölçme & $>$ Ölçme & $>$ Ölçme \\
\hline$>$ Veri & $>$ Veri & $>$ Veri İşleme \\
\hline
\end{tabular}

programda da 4 öğrenme alanının belirlendiği görülmektedir. 2009 programında sayılar olarak geçen öğrenme alanının 2015 ve 2017 programında sayılar ve işlemler olarak değiştirildiğini ve 2009 ile 2015 programında veri olan öğrenme alanının 2017 programında veri işleme olarak değiştirildiği gözlenmiştir.

\section{9, 2015 ve 2017 yullarındaki programlarda öğrenme üniteleri}

Tablo 6. 2009, 2015 ve 2017 yillarındaki programlarda üniteler

\begin{tabular}{|c|c|c|}
\hline 2009 & 2015 & 2017 \\
\hline $\bar{D}$ & $>$ 1. Ünite & $>\quad$ 1. Ünite \\
\hline$>$ & $>\quad$ 2. Ünite & $>\quad$ 2. Ünite \\
\hline$>$ & $>$ 3. Ünite & $>$ 3. Ünite \\
\hline$>$ & $>$ 4. Ünite & 4. Ünite \\
\hline$>$ & $>\quad$ 5. Ünite & $>$ 5. Ünite \\
\hline$>$ & $>\quad$ 6. Ünite & $>$ 6. Ünite \\
\hline
\end{tabular}

ünitelere ayrılmadığı görülürken, öğretmenlere ünitelendirilmiş yıllık plan yapmaları, 2015 ve 2017 programlarında ise ünite temelli bir yaklaşımın benimsendiği ve öğretmenden ders öncesi ders ile ilgili zihninde planlama yapması önerilmiştir. Buna ek olarak, 2015 ve 2017 matematik dersi programlarında her sınıf düzeyi için 6 ayrı ünite oluşturulmuş ve "Ünite-1, Ünite 2" şeklinde isimlendirme yapıldığg görülmektedir.

\section{9, 2015 ve 2017 yullarındaki programlarda beceriler}

Tablo 7. 2009, 2015 ve 2017 yıllarındaki programlarda beceriler 


\begin{tabular}{l}
\hline$>-$ \\
\hline$>-$ \\
$>--$ \\
$>--$ \\
$>-$ \\
$>--$ \\
$>--$ \\
$>--$ \\
$>--$ \\
$>--$ \\
$>--$ \\
$>--$ \\
$>$ Günlük dili, matematiksel dil ve \\
\\
$>$ sembollerle ilişkilendirme \\
$>$ İletişim \\
$>$ Problem çözme \\
$>$ Akıl yürütme \\
$>$ Bilgi teknolojilerini kullanma
\end{tabular}

$>-$

$--$

Eleştirel düşünme

Yaratıcı düşünme

> Türkçeyi doğru, etkili ve güzel kullanma

$>$ Araştırma

$>$ Karar verme

$>$ Girișimcilik

$>$ İlișkilendirme

$>$ Karar verme

Bilgi teknolojilerini kullanma

> Girişimcilik

> Problem çözmeyi, matematiksel kavramları irdeleme ve anlama için kullanma

> Matematiksel ve günlük yaşam durumlarını kullanarak problem kurma

$>$ Çözümlerin probleme uygunluğunu ve akla yatkınlığını kontrol etme ve yorumlama

$>$ Matematiği anlamlı bir şekilde kullanmak için öz güven ve olumlu tutum geliştirebilme

$>$ Değişik problemleri çözebilmek için farklı problem çözme stratejileri kullanabilme

> Somut model, şekil, resim, grafik, tablo vb. temsil biçimlerini kullanarak matematiksel düşüncelerini ifade etme

> Matematik ve problemler hakkındaki düşüncelerini açık

2017

Bilgi ve iletişim teknolojileri

Ana dilde iletişim

$>$ Yabanci dillerde iletişim

$>$ Dijital yetkinlik

Öğrenmeyi öğrenme

$>$ Sosyal ve vatandaşlıkla ilgili yeterlilik

> İnsiyatif alma ve girişimcilik algısı

$>$ Kültürel farkındalık ve ifade

$>$ Matematiksel süreç becerileri

Matematiksel modelleme

$--$

Duyuşsal beceriler

Matematik dilini kullanarak iletişim

> Psikomotor beceriler

İletişim

$>$ Problem çözme

$>$ Ak1l yürütme

Bilgi teknolojilerini kullanma

$>$ Matematiksel modelleme

$>$ İlişkilendirme

$>$ Duyuşsal beceriler

$>-$

Psikomotor beceriler

İletişim

$>$ Problem çözme

$>$ Ak1l yürütme

$>$ Matematiksel yetkinlik ve bilim/teknolojide temel yetkinlikler

Araç gereçleri uygun biçimde kullanma

Problem kurma

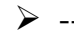

$>$ -

$>-$

$>-$

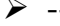

$>-$

$>-$

$>$-.

$>$--

$>$--

$>$--

$>$--

$>$--

$>$--

$-$

$>-$ --

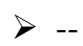

$>$.

$>$--

$>$-.

$>$ -

$>$ -

$>-$

$>$--

$>$--
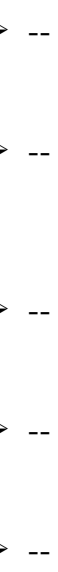
bir şekilde sözlü ve yazılı ifade etme

Matematik hakkında konuşma, yazma, tartışma ve okumanın önemini fark etme

> Mantığa dayalı çıkarımlarda bulunma

Kendi düşüncelerini açıklarken matematiksel modeller, kurallar ve ilişkileri kullanma

$>$ Probleme ilişkin çözüm yollarını > -ve cevapları savunma

$>$ Bir matematiksel durumu analiz $>$-ederken örüntü ve ilişkileri kullanma

> Matematiğin mantıklı ve anlamlı bir alan olduğuna inanma

> Matematikteki örüntü ve ilişkileri analiz etme

Tahminde bulunma

> Kavramsal ve işlemsel bilgiyi ilişkilendirme

> Matematiksel kavram ve kuralları çoklu temsil biçimleriyle gösterme

> Öğrenme alanları arasında ilişki kurma

Matematiği diğer derslerde ve günlük yaşamında kullanma

2009, 2015 ve 2017 programları incelendiğinde programlarda yer alan temel becerilerin y1llara göre dağılımı 2009 y1lı programında 4, 2015 y1lı programında 6, ve 2017 yılı programında ise 9 temel beceri olarak vurgulanmıştır. Buna karşın programın içeriği incelendiğinde kazandırılması beklenen 2009 yılında 35 olan beceri sayısının 2015'te 9, 2017'de 17 olduğu tespit edilmiştir. 2009 yılı programında yer alan 5 beceri 2015 ve 2017 programlarında aynen kalmıştır. 2009 programında yer alıp 2015 ve 2017 programında yer almayan 29 beceri yerine ise 2015 programında "araç gereçleri uygun biçimde kullanma, matematiksel modelleme, duyuşsal beceriler ve problem kurma" olmak üzere 4 yeni beceri, 2017 programında ise "bilgi ve iletişim teknolojileri, ana dilde iletişim, yabancı dillerde iletişim, dijital yetkinlik, ögrenmeyi öğrenme, sosyal ve vatandaşlıkla ilgili yeterlilik, insiyatif alma ve girişimcilik algısı, kültürel farkındalık ve ifade, matematiksel süreç becerileri, matematiksel modelleme ve duyuşsal beceriler” olmak üzere 12 yeni becerinin yer aldığ 
YYÜ Ĕ̆itim Fakültesi Dergisi (YYU Journal Of EducationFaculty),2017; 14(1):1219-1258, http://efdergi.yyu.edu.tr http://dx.doi.org/10.23891/efdyyu.2017.44

ISSN:1305-020

görülmektedir. Tablo 7 incelendiğinde 2009 ve 2015 programından farklı olarak 2017 programında yer alan 16 becerinin 8 tanesini Türkiye Yeterlilikler Çerçevesi'nde hayat boyu öğrenme kapsamında her bireyin kazanması beklenen sekiz anahtar yetkinlik oluşturmaktadır.

\section{9, 2015 ve 2017 yullarındaki programlarda dĕ̌gerler}

Tablo 8. 2009, 2015 ve 2017 yıllarındaki programlarda dĕ̆erler

\begin{tabular}{|c|c|c|}
\hline 2009 & 2015 & 2017 \\
\hline$\overline{D--}$ & $>-$ & $>$ Adalet \\
\hline$>--$ & $>-$ & > Paylașım \\
\hline$>--$ & $>-$ & > Bilimsellik \\
\hline$>--$ & $>--$ & $>$ Esneklik \\
\hline$>--$ & $>--$ & $>$ Essitlik \\
\hline$>--$ & $>--$ & > Özgürlük \\
\hline$>--$ & $>-$ & $>$ Sabir \\
\hline$>--$ & $>--$ & $>$ Sayg 1 \\
\hline$>--$ & $>-$ & $>$ Sorumluluk \\
\hline$>--$ & $>-$ & $>$ Tasarruf \\
\hline
\end{tabular}
programında değerler adı altında yeni bir bölüm oluşturulduğu ve on adet değere yer verildiği tespit edilmiştir.

2009, 2015 ve 2017 yullarındaki programlarda aradisiplinlere

Tablo 9. 2009, 2015 ve 2017 ylllarındaki programlarda aradisiplinler

\begin{tabular}{|c|c|c|}
\hline 2009 & 2015 & 2017 \\
\hline$>$ Sağlık kültürü & $D--$ & $D--$ \\
\hline$>$ İnsan hakları ve vatandaşlık & $>--$ & $>--$ \\
\hline$>$ Girişimcilik & $>--$ & $>--$ \\
\hline$>$ Kariyer bilinci geliştirme & $>--$ & $>--$ \\
\hline Rehberlik ve psikolojik danışma & $>--$ & $>--$ \\
\hline > Spor kültürü ve olimpik eğitim & $>--$ & $>--$ \\
\hline > Afetten korunma ve güvenli yaşam & $>--$ & $>--$ \\
\hline
\end{tabular}

2009 matematik dersi öğretim programında "sağlık kültürü, insan hakları ve vatandaşlık, girişimcilik, kariyer bilinci geliştirme, rehberlik ve psikolojik danışma, spor kültürü ve olimpik eğitim, afetten korunma ve güvenli yaşam" olmak üzere 7 ara disiplinin olduğu görülürken, 2015 ve 2017 matematik dersi öğretim programlarında aradisiplin anlayışının terk edildiği görülmektedir.

2009, 2015 ve 2017 yıllarındaki programlarda eğitim durumları 2009, 2015 ve 2017 yullarındaki programlarda öğrenme öğretme süreçleri 
2009 programında öğrenme öğretme süreçlerine ilişkin açıklamalar programın temel ögeleri başlığı altında 15 maddede sıralanmıştır ve toplam 15 sayfada yer almaktadır (MEB, 2009:63-77). 2015 ve 2017 programında ise; 2015 programında programın uygulanmasına ilişkin açıklamalar başlığı altında 12 madde olarak, 2017 programında ise öğretim programının uygulanmasında dikkat edilecek hususlar başlığı altında olmak üzere 13 madde olarak yer almaktadır. 2015 ve 2017 programlarında yer alan açıklamalara bakıldığında programların 2009 programından tamamen farklı olduğu görülürken, 2015 programında yer alan 11 açıklamanın biçimsel olarak tamamen olmasa da anlamsal olarak birebir korunduğu görülmektedir. Buna karşın "Özel ĕgitim ihtiyacı olan öğrencilerin özellikleri, eğitim performansları ve ihtiyaçları doğrultusunda Rehberlik Araştırma Merkezi'ndeki uzmanlarla iletişime geçilmelidir." ifadesi yerine kazanımların işıleniş süreleri ve Türkiye Yeterlilikler Çerçevesi'nde belirtilen becerilerin kazanımlarla ilişkilendirilmesinin gerekliliği ile ilgili açıklamanın verildiği saptanmıştır.

2009, 2015 ve 2017 yıllarındaki programlarda etkinlik örneklerine ilişkin açıklamalar

2009 matematik dersi öğretim programı incelendiğinde her kazanıma özel bir etkinlik örneğine yer verilirken 2015 ve 2017 programlarında etkinlik örneklerinin verilmediği saptanmıştır.

2009, 2015 ve 2017 yıllarındaki programlarda kazanımlar ve etkinlikler için açıklamalar

2009, 2015 ve 2017 matematik dersi öğretim programlarında kazanımlar ve etkinlikler için açıklamalara yer verildiği görülmektedir. 2009 matematik dersi öğretim programında her kazanım ve etkinlik örneği için açıklamalar ayrı ayrı oluşturulmuş ve bu açıklamalarda etkinliklerin ve kazanımların ilişkilendirileceği beceriler, ara disiplinler, sınıf içi ve sınıf dışı etkinlik bilgisi, diğer derslerle, olan ilişkilendirmeleri yer almaktadır. 2015 ve 2017 
programında ise bazı kazanımlar için sadece açıklamalara yer verilirken bazı kazanımlar için hem açıklama yapılmış hem de etkinlik örnekleri verilmiştir.

\section{9, 2015 ve 2017 yullarındaki programlarındaki ders saatleri}

Tablo 10. 2009, 2015 ve 2017 ylllarındaki programlarındaki ders saatleri

\begin{tabular}{|c|c|c|c|c|c|c|}
\hline \multicolumn{2}{|r|}{2009} & \multicolumn{3}{|c|}{2015} & \multicolumn{2}{|c|}{2017} \\
\hline \multirow{6}{*}{$\begin{array}{l}\bar{\Xi} \\
\text { क } \\
-\end{array}$} & \multirow{6}{*}{$>-$} & & $>1$. Ünite & 23 & $>1$. Ünite & 13 \\
\hline & & \multirow{5}{*}{144} & $>2$. Ünite & 31 & $>2$. Ünite & 52 \\
\hline & & & > 3. Ünite & 32 & > 3. Ünite & 32 \\
\hline & & & $>$ 4. Ünite & 24 & $>$ 4. Ünite & 32 \\
\hline & & & $>$ 5. Ünite & 35 & $>$ 5. Ünite & 26 \\
\hline & & & $>$ 6. Ünite & 35 & $>$ 6. Ünite & 25 \\
\hline \multirow{8}{*}{$\begin{array}{l}\vec{B} \\
\vec{N}\end{array}$} & \multirow[t]{3}{*}{ Toplam } & \multirow[t]{3}{*}{144} & Toplam & 180 & Toplam & 180 \\
\hline & & & $>1$. Ünite & 38 & $>1$. Ünite & 30 \\
\hline & & & $>2$. Ünite & 26 & $>2$. Ünite & 25 \\
\hline & \multirow{4}{*}{$>-$} & \multirow{4}{*}{144} & $>3$. Ünite & 25 & > 3. Ünite & 26 \\
\hline & & & $>$ 4. Ünite & 44 & $>$ 4. Ünite & 36 \\
\hline & & & $>$ 5. Ünite & 27 & $>$ 5. Ünite & 27 \\
\hline & & & $>$ 6. Ünite & 20 & $>$ 6. Ünite & 36 \\
\hline & \multirow[t]{3}{*}{ Toplam } & \multirow[t]{3}{*}{144} & Toplam & 180 & Toplam & 180 \\
\hline & & & $>1$. Ünite & 38 & $>1$. Ünite & 32 \\
\hline \multirow{5}{*}{$\begin{array}{l}\vec{B} \\
\dot{\mathscr{D}}\end{array}$} & & & $>2$. Ünite & 26 & $>2$. Ünite & 26 \\
\hline & \multirow{4}{*}{$>--$} & \multirow{4}{*}{144} & > 3. Ünite & 25 & > 3. Ünite & 36 \\
\hline & & & $>$ 4. Ünite & 44 & $>4$. Ünite & 36 \\
\hline & & & $>$ 5. Ünite & 27 & $>$ 5. Ünite & 22 \\
\hline & & & > 6. Ünite & 20 & $>$ 6. Ünite & 28 \\
\hline \multirow{8}{*}{$\begin{array}{l}\bar{\Xi} \\
\bar{W} \\
\dot{+}\end{array}$} & Toplam & 144 & Toplam & 180 & Toplam & 180 \\
\hline & & & $>1$. Ünite & 22 & $>1$. Ünite & 28 \\
\hline & \multirow{5}{*}{$>-$} & \multirow{5}{*}{144} & $>2$. Ünite & 30 & $>2$. Ünite & 22 \\
\hline & & & $>$ 3. Ünite & 38 & $>$ 3. Ünite & 34 \\
\hline & & & $>$ 4. Ünite & 22 & $>4$. Ünite & 30 \\
\hline & & & $>$ 5. Ünite & 34 & $>$ 5. Ünite & 35 \\
\hline & & & $>$ 6. Ünite & 34 & $>$ 6. Ünite & 31 \\
\hline & Toplam & 144 & Toplam & 180 & Toplam & 180 \\
\hline & Genel Toplam & 576 & Genel Toplam & 720 & Genel Toplam & 720 \\
\hline
\end{tabular}

programları karşılaştırıldığında tüm sınıf düzeylerinde ders saatlerinin 2015 yılında artırıldığı ve bu artışın 2017 yılında da korunduğu görülmektedir. Her bir sınıf düzeyi için uygun görülen süre bütün programlarda birbiri ile eşit olduğu gibi, 2009 programında bu her sınıf düzeyi için bu süre 144 saat, 2015 ve 2017 programlarında ise 180 saat olarak saptanmıştır. 2015 ve 2017 programlarını ünite bazında karşılaştırılacak olunursa her sınıf düzeyi için ayrılan toplam ders saati aynı olmasına karşın ünite bazında bakıldığında farklılık gösterdiği görülmektedir. 
2009 matematik dersi öğretim programında değerlendirme ile ilgili olarak program kitabında toplam 11 sayfanın yer aldığı saptanmıştır (MEB, 2009: 48-58). 2015 matematik dersi programında ise değerlendirme boyutu 2009 programına göre daha sınırlı düzeyde verilmiş olup, program kitabının 9. sayfasında "programın ölçme değerlendirme yaklaşımı" başlı̆̆1 altında 1,5 sayfadan oluşan bir açıklama olarak verilmiştir (MEB, 2015; 9-10). 2017 programının 2009 programına göre daha sade olma özelliği 2017 programını 2015 programına benzemektedir ancak 2015 programına göre daha kapsamlı bir değerlendirme açıklaması yer almaktadır. 2017 programında değerlendirmenin "tanıma”, “izlemebiçimlendirme" ve "sonuç (ürün) odaklı" olmak üzere üç aşamada gerçekleştirilmesi gerektiği vurgulanmıştır. Her üç programda değerlendirme anlayışlarının hem ürünü hem de süreci ölçmeye yönelik olduğu görülmektedir. Bunun yanında 2009 programında değerlendirmelerin hangi araçlarla yapılacağı, kazanımlarla ilişkilendirmek suretiyle örneklendirilerek açıklandığı görülmektedir. 2015 ve 2017 programında, 2009 programlarından farklı olarak akran değerlendirmesinin değerlendirme kapsamında yer aldığı görülmektedir.

\section{Sonuç ve Tartışma}

2009 matematik dersi öğretim programı incelendiğinde görülen vizyon başlı̆̆ 2015 ve 2017 programlarında görülmemektedir. 2009 programında vizyon başlığı ile verilen ilkokulu tamamlayan bir öğrencinin sahip olması beklenen (a) Problem çözebilen, (b) Çözümlerini ve düşüncelerini paylaşabilen, (c) Ekip çalışması yapabilen, (ç) Matematikte özgüven duyabilen ve (d) Matematiğe yönelik olumlu tutum geliştiren ifadelerinin 2015 ve 2017 programlarında olmadığı görülmektedir. 2017 programında ise programın felsefesi başlığı altında (1) başkalarının duygularını anlama, (2) grup etkinliklerinde yer alma, (3) cömertlik, (4) yardımseverlik, (5) başkalarıyla iletişimde bulunma, (6) müzakere etme, (7) sorun çözme, (8) kendisiyle ve toplumuyla uyum içinde olma, (9) sorumluluklarını bilen ve 
gereğini yerine getirebilen, (10) bir yandan millî, diğer yandan da evrensel değerleri içselleştirmiş, (11) öz güven sahibi ifadelerine yer verildiği görülmektedir. 2017 programında geçen (2) grup etkinliklerinde yer alma ve (7) sorun çözme ifadelerinin 2009 programında geçen (a) Problem çözebilen, (b) Çözümlerini ve düşüncelerini paylaşabilen ifadeleri ile örtüştüğü söylenebilir. 2017 programında yer alan (8) kendisiyle ve toplumuyla uyum içinde olma, (9) sorumluluklarını bilen ve gereğini yerine getirebilen, (10) bir yandan millî, diğer yandan da evrensel değerleri içselleştirmiş, (11) öz güven sahibi ifadelerinin ise çağımızın gereği olarak her bireyde olması beklenen özellikler olarak düşünülebilir.

2009 yılı programının vizyonunda yer alırken 2015 ve 2017 y1lı programlarında yer almayan (ç) Matematikte özgüven duyabilen ve (d) Matematiğe yönelik olumlu tutum geliştiren ifadelerinin yer almamasına karşın matematiğe yönelik olumlu tutum geliştirme ifadesi 2015 ve 2017 yılı programlarının hedefler bölümünde yer aldığını olumlu bir gelişme olarak ifade edilebilir. Çünkü öğrencilerin matematik dersine karşı tutumlarının akademik başarılarına etkisini araştıran araştırmalara bakıldığında, genel yarg1 matematiğe karşı geliştirilen olumlu tutumun matematik başarısına katkısı olduğu yönündedir (Yücel ve Koç, 2011; Peker ve Mirasyedioğlu, 200). Bununla birlikte yapılan bazı çalışmalarda matematik kaygısı, bireyin okul ve sosyal yaşamında karşılaştığı problemlerin çözümünde, sayılarla ilgili işlemler yapma durumlarında duygusal gerilim veya kaygı duyma şeklinde kendini gösterdiği belirtilmiştir (Adal ve Yavuz, 2017; Tobias, 1993).

2009 matematik dersi öğretim programında programın yaklaşımı olarak bir bölüm ayrılmış olup kavramsal yaklaşımın benimsendiği belirtilmiştir. Ancak 2009, 2015 ve 2017 matematik dersi programları incelendiğinde her üç programında tematik ve öğrenci merkezli yaklaşım anlayışlarını benimsediği görülmektedir. 2015 ve 2017 programlarında ayrıca ünite temelli bir yaklaşım benimsendiği görülmektedir. 2015 ve 2017 programlarında yaklaşım olarak bir bölüm ayrılmazken bu durum 2015 programında “matematik dersi öğretim 
programlarının genel amaçları" bölümünde, 2017 programında ise “öğretim programında değerler eğitimi” bölümünde öğretmenlere yaklaşım konusunda esneklik sunulduğu ve tek bir yaklaşıma bağlı kalınmaması gerektiği şeklinde açıklanmıştır.

2017 y1lı programında öğretmene yaklaşım konusunda esneklik sunulurken, kavramsal yaklaşımın da programda verilmesi ve bu anlayışa göre içeriğin organize edilmesi programın kazandırılması hedeflenen "problem çözme", "akıl yürütme" ve "ilişkilendirme" becerilerin kazandırılmasında fayda sağlayacağı düşünülmektedir. Gündoğdu ve diğerlerine göre (2012) kavramsal yaklaşım esas alınarak hazırlanan programlarda öğrenme alanları ile matematiksel kavramları anlayabilecek, öğrendiği kavramlar arasında ilişki kurabilecek, bu kavramları günlük hayat ve diğer öğrenme alanlarında kullanabilecek, matematiksel problemleri çözme süreci içerisinde kendi matematiksel düşünme ve akıl yürütme becerisini geliştirecek ve problem çözme stratejileri geliştirerek bu stratejileri günlük hayatta olabilecek problemlerde kullanabilen bireylerin yetiştirilmesi amaçlanmıştır.

2009, 2015 ve 2017 yıllarındaki programları incelendiğinde her üç programda da hedeflerin yer aldığı görülmektedir. 2009 programında 2015 ve 2017 programından farklı olarak "Türk Millî Eğitiminin Amaçları" başlığı altında ayrıca bir bölüm oluşturulmuştur. Bununla birlikte 2009 programında programın temel ögeleri bölümü altında oluşturulan matematik eğitiminin genel amaçları alt başlıkla kazandırılmak istenen 15 maddelik matematik eğitiminin genel amaçlarına ayrıca yer verilirken, 2015 programında 12 ve 2017 programında ise 13 maddelik amaçlar listesi oluşturulduğu görülmektedir. 2009 programında yer alan 8 hedefin 2015 ve 2017 programlarında da yer aldığı görülmektedir. Ayrıca 2015 programında yer alan bütün amaçlar 2017 programında da kendisine yer bulmuştur. 2015 programından farklı olarak "matematiğin insanlığın ortak bir değeri olduğunun bilincinde olarak matematiğe değer verecektir” amaç cümlesi 2017 programında yer almıştır. 
2009 ve 2015 y1lı programlarında yer alan (a) Matematiksel kavramları anlayabilecek, bu kavramları günlük hayatta kullanabilecektir, (b) Matematiksel düşüncelerini mantıklı bir şekilde açıklamak ve paylaşmak için matematiksel terminoloji ve dili doğru kullanabilecektir, (ç) Tahmin etme ve zihinden işlem yapma becerilerini etkin bir şekilde kullanabilecektir ifadelerinin 2017 yılı programında da yer alması, olumlu bir gelişme olarak değerlendirilmiştir. Kilpatrick, Swafford \& Findell'e göre (2001:8 akt. Demir ve Vural, 2017) "bir kimsenin başarılı bir şekilde matematik öğrenmesi” ifadesinin karşılığını birbiri içerisinde yer alan “(1) matematiği anlama, (2) akıcı bir şekilde hesap yapma, (3) problemleri çözmek için kavramları uygulamaya koyma, (4) mantıksal akıl yürütme ve (5) matematiği mantıklı, yararlı ve yapılabilir görerek; matematikle ilgilenme.” olmak üzere 5 bileşenden oluşan "matematiksel yeterlilik" terimi ile açıklamışlardır.

2009 yılı matematik dersi öğretim programında toplam 256 kazanım, 2015 yılı matematik dersi öğretim programında toplam 252 ve 2017 yılı matematik dersi öğretim programında ise toplam 229 kazanımın yer aldığı tespit edilmiştir. $\mathrm{Bu}$ perspektiften bakıldığında 2017 yılındaki kazanım sayısındaki azalmanın 2015 yılındaki azalmadan daha fazla olduğu görülmektedir. Sınıf düzeyinde bakıldığında 2015 programında ikinci ve dördüncü sınıf düzeylerinde azalma, birinci ve üçüncü sınıf düzeylerinde ise birer artış olduğu görülmekte iken, 2017 yılında birinci, ikinci ve dördüncü sınıf düzeylerindeki kazanım sayılarının azaltıldığı, üçüncü sınıf düzeyinde artış olduğu tespit edilmiştir.

2009, 2015 ve 2017 yılı programlarında öğrenme alanlarına, üniteler, beceriler, değerler ile aradisiplinler konularının yer alıp almadıkları karşılaştırmalı olarak incelenmiştir. 2009 yılı matematik dersi öğretim programı incelendiğinde (a) sayılar, (b) geometri (c) ölçme ve (d) veri öğrenme alanlarının küçük değişiklikler ile 2015 ve 2017 yılı programlarında yer aldığı tespit edilmiştir. 2009 yılı programında sayılar olarak geçen öğrenme alanının 2015 ve 2017 yılı programlarında sayılar ve işlemler olarak, 2009 ile 2015 
programında veri olan öğrenme alanının 2017 programında veri işleme olarak değiştirildiği tespit edilmiştir.

2009 ve 2015 yılı programlarında yer alan öğrenme alanlarının 2017 programında korunuyor olması olumlu olarak değerlendirilebilir. Erdoğan ve diğerleri (2017) yapmış oldukları çalışmada Türkiye'deki matematik programındaki öğrenme alanları dağılımının, Trends in International Mathematics and Science Study (TIMSS) dağılımı ile uyumlu olduğu belirlemiştir. Öğrenme alanlarının uluslararası alanda başarılı sayılabilecek düzeyde olmasına karşın, öğrenci başarısızlığının nedeni olarak ders kitapları ve çalışma kitaplarının programlara uygun hazırlanmıyor olması söylenebilir (Toptaş, Elkatmış ve Karaca, 2012).

2009 yılı programında programın ünitelere ayrılmadığı görülürken öğretmenlere ünitelendirilmiş yıllık plan yapmaları önerilmiştir. 2015 ve 2017 programlarında ise program yaklaşımına uygun olarak her sınıf düzeyi için 6 ayrı ünite oluşturulmuş ve " ̈̈nite-1, Ünite2" şeklinde isimlendirme yapılmıştır.

2009 y1lı programında yer alan 4 temel beceri 2015 y1lı programında 6, 2017 yılı programında ise 9 olarak karşımıza çıkmaktadır. Temel beceriler ile birlikte programlarda kazandırılması beklenen toplam beceri sayıları ise 2009 yılı programında 35 beceri 2015 yıl1 programında 9 ve 2017 yılı programında ise 17 olarak karşımıza çıkmaktadır. 2009 yılı programında yer alan (1) iletişim, (2) problem çözme, (3) bilgi teknolojilerini kullanma, (4) ak1l yürütme, (5) psikomotor becerilerinin 2015 ve 2017 yılı programlarında da yer aldığ saptanmıştır. 2015 programında "araç gereçleri uygun biçimde kullanma, duyuşsal beceriler ve problem kurma" olmak üzere 3 yeni becerinin, 2017 programında ise "bilgi ve iletişim teknolojileri, ana dilde iletişim, yabancı dillerde iletişim, dijital yetkinlik, öğrenmeyi öğrenme, sosyal ve vatandaşlıkla ilgili yeterlilik, insiyatif alma ve girişimcilik algısı, kültürel farkındalık ve ifade, matematiksel süreç becerileri, matematiksel modelleme ve duyuşsal beceriler” olmak üzere 12 yeni becerinin yer aldığı görülmektedir. 
2009, 2015 ve 2017 programlarına bakıldığında "problem çözme" becerisi gibi bazı becerilerin korunması olumlu olarak değerlendirilebilir. Matematik programları incelendiğinde "Problem çözme" becerisinin matematik dersi programının odağını oluşturduğu söylenebilir (Olkun ve Toluk Uçar, 2012). Smith’e göre (2009 akt. İskenderoğlu ve Uzuner, 2017) "problem çözme" becerisi eğitimin temel hedeflerinden biridir. Benzer şekilde NCTM' ye (National Council of Teachers of Mathematics) göre, problem çözme becerisi ve stratejileri matematik eğitiminde oldukça önemli bir yere sahiptir (NCTM, 2000).

2017 yılı programı ile birlikte 2009 ve 2015 yılı programlarından farklı olarak matematik dersi programında değerler başlığının kullanıldığı görülmektedir. Değerler başlı̆g1 altında (1) adalet, (2) paylaşım, (3) bilimsellik, (4) esneklik, (5) eşitlik, (6) özgürlük, (7) sabır, (8) saygı, (9) sorumluluk ve (10) tasarruf”' olmak üzere 10 adet değere yer verildiği tespit edilmiştir. 2009 y1lı matematik dersi öğretim programında 7 aradisiplinin olduğu görülürken, 2015 ve 2017 yılı matematik dersi öğretim programlarında aradisiplin anlayışının terk edildiği görülmektedir.

Programlarda öğrenme öğretme süreçlerine ilişkin açıklamalara 2009 yılında 15 madde, 2015 y1lı programında 12 ve 2017 yılı programında ise 13 madde olarak yer verildiği saptanmıştır. 2015 ve 2017 programlarında yer alan açıklamalara bakıldığında 2009 programından tamamen farklı olduğu görülürken 2015 programında yer alan 11 açıklamanın biçimsel olarak tamamen olmasa da anlamsal olarak birebir korunduğu görülmektedir. Buna karşın 2015 programında yer alan "Özel eğitim ihtiyacı olan öğrencilerin özellikleri, eğitim performansları ve ihtiyaçları doğrultusunda Rehberlik Araştırma Merkezi’ndeki uzmanlarla iletişime geçilmelidir” açıklamasının 2017 yılı programında yer almadığı tespit edilmiştir.

2009 matematik dersi öğretim programı incelendiğinde kazanımın tek tek belirtildiği ve her kazanıma özel bir etkinlik örneğine yer verilirken 2015 ve 2017 programlarında bu anlayışın terk edildiği tespit edilmiştir. Sadece bazı kazanımlar için soru örnekleri oluşturmak 
amacıyla etkinlik örneği verilmiştir. Etkinlik örnekerinin 2009 programından sonra terk edilmesi ve bu anlayışı 2015 ve 2017 programlarında sürdürülüyor olması olumsuz bir durum olarak değerlendirilebilir.

2009, 2015 ve 2017 yılı programlarının tamamında kazanımlar ve etkinlikler için açıklamalara yer verildiği görülmektedir. 2009 yılı programında her kazanım ve etkinlik örneği için açıklamalar ayrı ayrı oluşturulmuş ve bu açıklamalarda etkinliklerin ve kazanımların ilişkilendirileceği beceriler, ara disiplinler, sınıf içi ve sınıf dışı etkinlik bilgisi, diğer derslerle, olan ilişkilendirmelere yer verilirken, 2015 ve 2017 y1lı programında bazı kazanımlar için sadece açıklamalara, bazı kazanımlar içinse hem açıklamalara hem de etkinlik örneklerine yer verilmiştir.

2009 yılı matematik dersi öğretim programı incelendiğinde tüm sınıf düzeylerinde yüz kırk dörder saat olan ders süresinin, 2015 ve 2017 yılı matematik dersi öğretim programlarında \%25 artırılarak 180 saat olduğu görülmektedir. Her bir sınıf düzeyi için toplam ders saatinin her programda kendi içinde tutarlılık gösterdiği söylenebilir. 2015 ve 2017 programlarını ünite bazında karşılaştırıldığında ise, her sınıf düzeyi için ayrılan toplam ders saati aynı olmasına karşın ünite bazında bakıldığında bu saatin farklılık gösterdiği görülmektedir.

2009 programında belirlenen ders saatleri, 2015 yılında artırıldığg ve bu artışın 2017 yılında korunduğu görülmektedir. 2009 programı ders saatleri boyutu ile TIMSS raporlarına göre matematik başarısı yüksek ülkelerin eğitim programları ile benzerlik göstermesine karşın haftalık ders dağılımları içerisinde matematik dersinin yeri oldukça düşük bir oranda karşımıza çıktığı görülür. Bu bağlamda ders saatlerinin artırılması yerine matematik dersinin ilkokul programı içerisindeki ders saati olarak oranının artırılması gerektiği söylenebilir (Erdoğan ve diğerleri, 2017). 
2009, 2015 ve 2017 yılı programları incelendiğinde her üç programda da değerlendirmeye yer verildiği görülmektedir. 2009 y1lı matematik dersi öğretim programında değerlendirme 11 sayfa olarak, 2015 ve 2017 yllı matematik dersi programlarında ise 1,5 sayfa olarak yer aldığı tespit edilmiştir. 2017 yılı matematik dersi programının değerlendirme boyutu sadeliği ile 2015 yılı programına benzese de, 2015 yılı programına göre daha kapsamlı bir değerlendirme açıklaması yer almaktadır. 2017 programında değerlendirmenin "tanıma", “izleme-biçimlendirme” ve "sonuç (ürün) odaklı" olmak üzere üç aşamada gerçekleştirilmesi gerektiği vurgulanmıştır. Bu bağlamda 2009, 2015 ve 2017 yılı programlarının ortak özelliği olarak süreç odaklı olduğu belirlenmiştir.

2009 yılı programında değerlendirmelerin nasıl yapılacağı, kazanımlarla ilişkilendirmek suretiyle örneklerle açıklanarak verilirken, 2015 ve 2017 yılı programlarında öğretmene değerlendirmenin hangi boyutlarda yapılması gerektiği belirtilmiştir. Ayrıca 2017 yılı programında 2009 ve 2015 programından farklı olarak akran değerlendirmesine de vurgu yapıldığı görülmektedir. Semra'ya göre (2012) değerlendirme kültüründe, süreç ve sonuç odaklı değerlendirme yapılırken öğrencilerin değerlendirme süresi içerisinde sorumluluk alan, aktif katılım gösteren, yansıtan, öz değerlendirme ve işbirliği yapan konumu söz konusudur. Süreçte öğrencinin bu konumu düşünüldüğünde alternatif değerlendirmelerin olması gerekmektedir. Bu bağlamda 2017 programı ile benimsenen akran değerlendirmesinin olumlu bir gelişme olduğu görülmektedir.

\section{Öneriler}

Yapılan bu çalışma sadece 2009, 2015 ve 2017 yıllarını kapsadığ i için karşılaştırma sadece bu üç programla sınırlı kalmıştır. Bundan sonra yapılacak çalışmalar için Türkiye’ de Cumhuriyet'in kuruluşundan günümüze yürürlüğe girmiş bütün matematik dersi programları tüm boyutları ile karşılaştırılması önerilmektedir. 
2009 programında benimsenen ancak 2015 ve 2017 programlarında yer almayan kavramsal yaklaşımın, ileriki yıllarda yapılacak olan program çalışmalarında tekrar benimsenmesi kavram öğretiminde faydalı olacağı söylenebilir. Alan yazı incelendiğinde matematik dersi özelinde öğrenme-öğretme sürecinde benimsenen yaklaşımların öğrencilerin yaşadıkları öğrenme güçlüklerinin sebeplerinden biri olarak vurgulanmaktadır (Sarı ve Tertemiz, 2017; Burns, 2007). Bu bağlamda matematik eğitiminde bazı becerilerin kazandırılması için genel prosedürlerin üzerinde durmak yerine kavramları anlamanın üzerinde durulması gerekmektedir (Sarı ve Tertemiz, 2017).

2015 ve 2017 programlarında yer almayan ancak 2009 programın var olan her kazanıma yönelik etkinlik örneği anlayışının da tekrar benimsenmesi gerektiği düşünülmektedir. Etkinlik örnekleri uygulayıcılara kazanımların nasıl verilmesi konusunda rehberlik yapmaktadır (Van De Walle, Karp \& Bay-Williams, 2012).

2009 programında yer alıp 2015 ve 2017 programında yer almayan daha kapsamlı bir değerlendirme bölümü ileriki yıllarda yapılacak program çalışmalarına eklenebilir. Programda önerilecek alternatif değerlendirmelerin öğretmenlerin çok yönlü bir değerlendirme anlayışını benimsemelerinde etkili olacağı söylenebilir.

\section{Makalenin Bilimdeki Konumu}

Temel Eğitim Bölümü,

\section{Sınıf Eğitimi Anabilim Dalı}

\section{Makalenin Bilimdeki Özgünlüğü}

Bu araştırmada, 2009, 2015 ve 2017 ilkokul matematik dersi öğretim programları hedefler, üniteler, eğitim durumu ve değerlendirme boyutları, programın vizyon ve yaklaşımı ele alınarak karşılaştırmalı olarak değerlendirilmiştir. Bu kapsamı ile bakıldığında literatürde var olan çalışmalarda bu kadar kapsamlı bir çalışmanın yer almadığı görülmektedir. Bununla birlikte alan yazında 2017 ilkokul matematik dersi programına yönelik hiçbir çalışma yer 
almamaktadır. Bu boyutu ile çalışmanın özgünlüğü ve alandaki boşluğu doldurması hedeflenmiştir.

\section{Kaynakça}

Adal, A. A. ve Yavuz, İ. (2017). Ortaokul öğrencilerinin matematik öz yeterlik algıları ile matematik kaygı düzeyleri arasındaki ilişki. Uluslararası Alan Eğitimi Dergisi, 3(1), 20-41.

Akman, B. (2002). Okul öncesi dönemde matematik. Hacettepe Üniversitesi Eğitim Fakültesi Dergisi, 23(1), 244-248.

Alak, G. ve Nalçac1, A. (2013). Hayat bilgisi öğretim programı öğelerinin öğretmen görüşlerine göre değerlendirilmesi. Buca Eğitim Fakültesi Dergisi, 33(1), 36-51.

Arseven, A., Kontaş, H. ve Arseven, İ. (2014). Matematik programının değerlendirme öğesine ilişkin sınıf öğretmenlerinin görüşleri. Adıyaman Üniversitesi Sosyal Bilimler Enstitüsü Dergisi, 7(18), 657-677.

Baş, S. (2016) İlkokul matematik dersi öğretim programlarının matematiksel modelleme bağlamında incelenmesi. İçinde: Özmantar, M. F., Öztürk, A. ve E.Bay (Eds.), Reform ve değişim bağlamında ilkokul matematik ögretim programları (ss. 425-454). Ankara: Pegem Akademi Yayıncılık.

Baş, M. (2015). The using of IWBs by primary school teacher in mathematics classrooms. International Journal of Eurasia Social Sciences, 6(21), 121-135.

Batd1, V. (2014). Ortaöğretim matematik öğretim programı içeriğinin rash ölçme modeli ve nvivo ile analizi. Turkish Studies International Periodical For The Languages, Literature and History of Turkish or Turkic, 9(11), 93-109.

Bayraktar, A., Güner, N., Denizli, Z. A. ve Sezer, R. (2016). Okul müdürlerinin Türkiye'nin matematik programı hakkındaki görüşlerini belirlemeye yönelik ölçek geliştirme çalışması. Ijaedu- International E-Journal of Advances in Education, 2 (5), 218-226. 
Bekdemir, M. ve Baş, F. (2017). Matematik öğretmenlerin, öğrencilerinin matematik bilgi ve becerilerini ölçerlerken kavram ve işlem bilgileri kullanma düzeyleri. Ondokuz Mayıs Üniversitesi Ĕ̌itim Fakültesi Dergisi, 36(1), 95-113

Bilgin, N. (2014). Sosyal bilimlerde içerik analizi teknikler ve örnek çalışmalar. Ankara: Siyasal Kitapevi.

Bloor, M., \& Wood, F. (2006). Keywords in qualitative methods: A vocabulary of research concepts. London: Sage Publications.

Bogdan, R. C. \& Biklen, S. K. (2003). Qualitative research methods for education: An Introduction to Theories and Methods, (4.Ed). Pearson Publications.

Bowen, G. A. (2009). Document analysis as a qualitative research method. Qualitative research journal, 9(2), 27-40. DOI 10.3316/QRJ0902027.

Bulut, S., Boz, B. ve Yavuz, F. D. (2016). 7. Sınıf matematik ders kitaplarında dönüşüm geometrisi işlenişinin öğretim programları açısından değerlendirilmesi. İlköğretim Online, 15(4), 1164-1190.

Bulut, S., Yavuz, F. D. Ve Boz-Yaman, B. (2017). Tahmin becerilerinin 1948'den 2015'e 15. Sınıflar matematik dersi öğretim programlarındaki yeri. Ahi Evran Üniversitesi Kırşehir Eğitim Fakültesi Dergisi (KEFAD), 18(1), 19-39.

Burns, M. (2007). About teaching mathematics A K-8 Resource. USA: Math Solutions.

Büyüköztürk, Ş., Kılıç Çakmak, E., Akgün, O. E., Karadeniz, S. ve Demirel, F. (2012). Bilimsel araştırma yöntemleri. Ankara: Pegem Akademi Yayıncılık.

Cooke, R. L. (2011). The history of mathematics: A brief course. New Jersey: John Wiley \& Sons, Inc.

Courant, Robbins, \& Stewart. (1996). What is mathematics? An elementary approach to ideas and methods. USA: Oxford University Press.

Creswell, J. W. \& Miller, D. L. (2000). Getting good qualitative data to improve educational practice. Theory Into Practice, 39(3), 124-130. 
Çakır, S. ve Kılınç, H. H. (2016). İlkokul 4. sınıf matematik dersi programına ilişkin öğretmenlerin görüşleri teachers'views with regard to the elementary school 4th grade mathematics lesson curriculum. Mehmet Akif Ersoy Üniversitesi Eğitim Fakültesi Dergisi, 1(39), 112-124.

Dağdelen, S. ve Ünal, M. (2017). Matematik öğrenim ve öğretim sürecinde karşılaşılan sorunlar ve çözüm önerileri, YYÜ Eğitim Fakültesi Dergisi (YYU Journal Of Education Faculty), 14, 483-510.

Demir, G. ve Vural, R. A. (2017). Ortaöğretim matematik programının hedeflediği matematiksel yeterlilik ve becerilerinin kazandırılma sürecinin öğretmen görüşleri temelinde incelenmesi. Adnan Menderes Üniversitesi, Sosyal Bilimler Enstitüsü Dergisi, 4(1), 118-139.

Demir, S. (2012). Öğretmen eğitimi bağlamında bir öğrenme ve değerlendirme yöntemi olarak portfolyo. Sosyal Bilimler Enstitüsü Dergisi, 32(1), 237-259.

Demirel, Ö. (1992). Türkiye'de program geliştirme uygulamaları. Hacettepe Üniversitesi, Ĕ̈itim Fakültesi Dergisi, 7(1), 27-43.

Dinç-Artut, P. ve Tarım, K. (2016). İlkokul matematik programlarının problem çözme açısından incelenmesi. İçinde M.F. Özmantar, A. Öztürk, ve E.Bay (Ed.). Reform ve değişim bağlamında ilkokul matematik öğretim programları (ss. 293-315). Ankara: Pegem Akademi Yayıncılık.

Duru, A. ve Korkmaz, H. (2010). Öğretmenlerin yeni matematik programı hakkındaki görüşleri ve program değişim sürecinde karşılaşılan zorluklar. Hacettepe Üniversitesi Ĕ̈itim Fakültesi Dergisi, 38(38), 67-81.

Ekiz, D. (2003). Eğitimde araştırma yöntem ve metodlarına giriş. Ankara: Anı Yayıncılık.

Erbilgin, E. (2014). Türkiye'nin ilkokul ve ortaokul matematik öğretim programlarının genel konu izleme haritası ile incelenmesi. Ĕgitim ve Bilim, 39(174), 272-285.

Erdoğan, F., Hamurcu, H. ve Yeşiloğlu, A. (2017). Türkiye, Singapur TIMSS 2011 sonuçlarının matematik programı açısından değerlendirilmesi. Cumhuriyet International Journal of Education CIJE, 5(1), 31-43. 
Ergün, M., Özmantar, M. F., Bay, E. ve Agaç, G. (2015). Cumhuriyetin ilanından günümüze eğitimde, program geliştirmede ve matematik programlarında yaşanan değişim ve gelişimler. İçinde: M. F. Özmantar, A. Öztürk ve E, Bay (Eds.), Reform ve değişim bağlamında ilkokul matematik öğretim programları (p. 407-424). Ankara: Pegem Akademi Yayıncılık.

Ersoy, E. ve Öksüz, C. (2016). İlkokul 4. sınıflarda matematik tarihi kullanımının öğrenciler üzerindeki etkileri. İlköğretim Online, 15(2), 408-420.

Fraenkel, J. R., \& Wallen, N. E. (1996). How to design and evaluate research in education. New York, NY: McGraw-Hill.

Gökkurt, B., Soylu, Y. ve Demir, Ö. (2015). Ortaokul matematik öğretmenlerinin kesirlerin öğretimine yönelik görüşlerinin incelenmesi. Necatibey Eğitim Fakültesi Elektronik Fen ve Matematik Ë̆itimi Dergisi, 9(2), 230-251.

Gözütok, F. D. (2003). Türkiye’de program geliştirme çalışmaları [Curriculum development studies in Turkey]. Millî Eğitim Dergisi [Journal of National Education], 160.

Gündoğdu, K., Albayrak, M., Ozan, C., ve Çelik, N. (2012). Müfettişlerin ilköğretim matematik öğretim programı hakkındaki görüşleri. Adnan Menderes Üniversitesi Ĕ̌itim Fakültesi Ĕgitim Bilimleri Dergisi, 3(2), 21-37.

Güneş, F. ve Uygun, T. (2016). Öğretmen yetiştirmede beceri uyuşmazlığı. Ahi Evran Üniversitesi Sosyal Bilimler Enstitüsü Dergisi (AEÜSBED), 2(3), 1-14.

Güngör, H. ve Çavuş, H. (2015). İlkokul 4. sınıf matematik dersi" kesirler" konusunun öğretiminde öğretmenin yardımcı kitap kullanımının öğrenci başarısı üzerindeki etkisi. Journal of Kirsehir Education Faculty, 16(2), 251-271.

Hannula, M. S. (2014). Affect in mathematics education. In S.Lerman (Ed) Encyclopedia of mathematics education (pp. 23-27). Dortrecht: Springer Netherlands.

Howson, G., Keitel, C. \& Kilpatrick, J. (2008) Curriculum Development in Mathematics. Cambridge: Cambridge University press. 
Işık, C. ve Kar, T. (2011). İlköğretim 6, 7 ve 8. sınıf öğrencilerinin sayı algılama ve rutin olmayan problem çözme becerilerinin incelenmesi. Ahi Evran Üniversitesi Eğitim Fakültesi Dergisi, 12(1), 57-72.

İskenderoğlu, T. A. ve Uzuner, F. G. (2017). Sinıf öğretmenlerinin ilkokul öğrencilerine temel matematiksel becerileri kazandırma sürecine ilişkin görüşleri. Abant İzzet Baysal Üniversitesi Eğitim Fakültesi Dergisi, 2(17), 563-585.

Kurnaz, F. B. ve Kutlu, Ö. (2016). İlkokul 4. sınıf için hazırlanan bilimsel süreç becerileri programının etkililiğinin belirlenmesi. İlköğretim Online, 15(2), 529-547.

Kuş, E. (2003). Nicel-nitel araştırma teknikleri. Ankara: Anı Yayıncılık

Lester, F. K. (2013). Thoughts about research on mathematical problem- solving instruction. The Mathematics Enthusiast, 10(1/2), 245-278.

Memnun, D., S. (2013). Türkiye'deki Cumhuriyet dönemi ilköğretim matematik programlarına genel bir bakış. Mehmet Akif Ersoy Üniversitesi Eğitim Fakültesi Dergisi, 13(25), 71-91.

Miles, M., B. \& Huberman, A., M., (1994). Qualitative data analysis: an expanded sourcebook (2nd ed.). California: SAGE Publications

MEB, (1948). İlkokul programı. İstanbul: Millî Eğitim Basımevi.

MEB, (2009). Matematik dersi ögretim programı ve kılavuzu (1.2.3.4.5. Sınıflar). Ankara.

MEB, (2015): Matematik dersi öğretim programı ve kılavuzu (1.2.3.4. Sınıflar). Ankara.

Millî Eğitim Bakanlığı Talim ve Terbiye Kurulu Başkanlığı (MEB-TTKB). (1990).illköğretim matematik dersi programı. Ankara: MEB.

Millî Eğitim Bakanlığı Talim ve Terbiye Kurulu Başkanlığı (MEB-TTKB). (1998). İlköğretim okulu matematik dersi ögretim programı. Ankara: MEB.

Millî Eğitim Bakanlığı Talim ve Terbiye Kurulu Başkanlığı (MEB-TTKB). (2005). Ilköğretim matematik programı. Ankara: MEB. 
Millı̂ Eğitim Bakanlığı Talim ve Terbiye Kurulu Başkanlığı (MEB-TTKB). (2015). İlkögretim matematik dersi (1, 2, 3 ve 4. Sinıflar) ögretim programı. Ankara: MEB.

Millî Eğitim Gençlik ve Spor Bakanlığı (MEB). (1968). Illkokul matematik programı. Ankara: MEB.

Millî Eğitim Gençlik ve Spor Bakanlığı (MEB). (1983). Illkokul matematik programı. Ankara: MEB.

Nasibov, F. Ve Kaçar, A. (2005). Matematik ve matematik eğitimi hakkında. Kastamonu Eğitim Dergisi, 13(2), 339-346.

NCTM. (2000). Principles and standards for school mathematics. Va: National Council of Teachers of Mathematics Pub.

Olkun, S. ve Toluk-Uçar Z. (2012). Illköğretimde etkinlik temelli matematik öğretimi. Ankara: Anı Yayıncilık.

Orbeyi, S. ve Güven, B. (2008). Yeni ilköğretim matematik dersi öğretim programı'nın değerlendirme öğesine ilişkin öğretmen görüşleri. Eğitimde Kuram ve Uygulama, 4(1), 133-147.

Öksüz, C. (2015). İlkokul matematik programını değerlendirme ölçeği. Pamukkale Üniversitesi Ĕ̈itim Fakültesi Dergisi, 1(37), 21-33.

Özdemir, S. M. (2009). Eğitimde program değerlendirme ve Türkiye'de eğitim programlarını değerlendirme çalışmalarının incelenmesi, Yüzüncü Yıl Üniversitesi Eğitim Fakültesi Dergisi, 6(2), 126-149.

Özdemir, B. G., Bayraktar, R. ve Yılmaz, M. (2017). Sınıf ve ortaokul matematik öğretmenlerinin kavram yanılgılarına ilişkin açıklamaları. Trakya Üniversitesi Ĕ̆itim Fakültesi Dergisi, 7(2), 284-305. Doi: 10.24315/trkefd.284301.

Özmantar, M. F. (2017). A historical analysis of primary mathematics curricula in terms of teaching principles. International Journal of Research in Education and Science (IJRES), 3(2), 327-342. Doi: 10.21890/ijres.327890. 
Özmantar, M. F., ve Öztürk, A. (2016). İlkokul matematik programlarının öğretim ilkeleri açısından incelenmesi. İçinde: M. F. Özmantar, A. Öztürk ve E, Bay (Eds.), Reform ve değişim bağlamında ilkokul matematik öğretim programları (p. 125-146). Ankara: Pegem Akademi Yayıncılık.

Özmantar, M. F., ve Öztürk, A. (2017). Problem solving skill in primary mathematics curricula documents of the republican period. Uluslararası International Journal of Social and Educational Sciences 4(7), 120-146.

Özmantar, M. F., Öztürk A., ve Bay, E. (2016). Reform ve değişim bağlamında ilkokul matematik öğretim programları. Ankara: Pegem Akademi Yayıncılık.

Peker, M. (2009). Sınıf öğretmenlerinin 2005 ilköğretim I. kademe matematik programının misyonuna ilişkin görüşlerinin bazı değişkenler açısından incelenmesi. Erzincan Eğitim Fakültesi Dergisi, 11(1), 33-51.

Peker, M. ve Halat, E. (2008). İlköğretim I. Kademe matematik programının eğitim durumları boyutunun öğretmen görüşleri doğrultusunda incelenmesi. Selçuk Üniversitesi, Ahmet Keleşoğlu Ĕ̈itim Fakültesi Dergisi, 26, 209-225.

Peker, M. ve Mirasyedioğlu, Ş. (2003). Lise 2. sınıf öğrencilerinin matematik dersine yönelik tutumları ve başarıları arasındaki ilişki. Pamukkale Üniversitesi Eğitim Fakültesi Dergisi,14(14), 157-166.

Sarı, M. H. ve Tertemiz, N. (2017). İlkokul 4. Sınıfta Dienes ilkelerine göre yapılandırılmış geometri etkinliklerinin öğrenci başarısına ve kalıcılığa etkisi. Eğitim ve Bilim, 42(190), 1-23. DOI: http://sci-hub.cc/10.15390/EB.2017.6161

Schoenfeld, A. H. (2004). The math wars. Educational Policy. 18(1), 253-286.

Sevimli, E. ve Kul, Ü. (2015). Matematik ders kitabı içeriklerinin teknolojik uygunluk açısından değerlendirilmesi: Ortaokul örneği. Necatibey Eğitim Fakültesi Elektronik Fen ve Matematik Eğitimi Dergisi, 9(1), 308-331.

Sezgin Memnun, D. (2013). Türkiye'deki Cumhuriyet dönemi ilköğretim matematik programlarına genel bir bakış. Mehmet Akif Ersoy Üniversitesi Eğitim Fakültesi Dergisi, 13(25), 71 - 91. 
Sönmez, V. ve Alacapınar, F., G. (2015). Örnekleriyle ĕgitimde program değerlendirme. Ankara: Anı Yayınc1lık.

Sriraman, B. \& English, L. (2010). Surveying theories and philosophies of mathematics education. In Sriraman, B., \& English, L (Ed) Theories of Mathematics Education: Advances in Mathematics Education. (pp. 7-32). Springer Berlin Heidelberg.

Şimşek, N. ve Boz, N. (2015). Sınıf öğretmeni adaylarının uzunluk ölçme konusunda pedagojik alan bilgilerinin öğrenci kavrayışları bağlamında incelenmesi. Cumhuriyet International Journal of Education, 4(3), 10-30.

Tay, B. (2017). 2005 Sosyal bilgiler dersi öğretim programı ile 2017 sosyal bilgiler dersi taslak öğretim programının karşılaştırması, International Journal of Eurasia Social Sciences, 8(27), 461-487.

Tertemiz, N. (2003). İlköğretim matematik öğretimine ilişkin yeni görüşler ve standartlara dayalı program anlayışı. Çă̆daş Ĕ̆itim, 304, 27-32.

Tobias, S. (1993). Overcoming math anxiety. New York: W.W. Norton ve Company.

Toptaş, V. (2011). Sınıf öğretmenlerinin matematik dersinde alternatif ölçme ve değerlendirme yöntemlerinin kullanımı ile ilgili algıları. Eğitim ve Bilim. 36(159), 205-219.

Toptaş, V., Elkatmış, M., Karaca, E. T., (2012). İlköğretim 4. Sınıf matematik programının öğrenme alanları ile matematik öğrenci çalışma kitabındaki soruların zihinsel alanlarının TIMSS'e göre incelenmesi. Ahi Evran Üniversitesi Kırşehir Eğitim Fakültesi Dergisi (KEFAD), 13 (1), 17-29.

Trautwein, U., Koller, O., Schmitz, B. \& Baumert, J. (2002). Do homework assignments enhance achievement? A multilevel analysis in 7th-grade mathematics. Contemporary Educational Psychology, 27, 26-50.

(http1)http://www.tdk.gov.tr/index.php?option=com_gts\&arama=gts\&guid=TDK.GTS.598a7 cd17b4a17.17142795 adresinden 09.08.2017 tarihinde erişilmiştir. 
Türkiye Cumhuriyeti Maarif Vekâleti. (1930). Illk mektep öğretim programı programı. İstanbul: Devlet Matbaası.

Türkiye Cumhuriyeti Kültür Bakanlığı. (1936). İlkokul programı. İstanbul: Devlet Basımevi.

Umay, A. (2002) Öteki matematik, Hacettepe Üniversitesi Eğitim Fakültesi Dergisi, 23(1), 275-281.

Umay, A., Çıkla, O. A. ve Duatepe, A. (2006). Matematik dersi 1.-5. sınıf öğretim programının NCTM prensip ve standartlarına göre incelenmesi. Hacettepe Üniversitesi Eğitim Fakültesi Dergisi, 31(31), 198-211.

Uygun, T., Gökkurt, B. ve Usta, N. (2016). Üniversite öğrencilerinin matematik problemine ilişkin algılarının metafor yoluyla analiz edilmesi. Bartın Üniversitesi Eğitim Fakültesi Dergisi, 5(2), 536-556.

Üçüncü, K. ve Tertemiz, N. (2012). İlköğretim (2-5. sınıflar) matematik dersi öğretim programı çarpma alt öğrenme alanının değerlendirilmesi. Türk Eğitim Bilimleri Dergisi. , 10(1), 97-122.

Vural, M. (1998). En son değişiklikleriyle ilköğretim okulu programı. Erzurum: Yakutiye Yayıncilik.

Van De Walle, A. J., Karp, S. K., \& Bay-Williams, M. J. (2012). Illkokul ve ortaokul matematiği gelişimsel yaklaşımla öğretim (7. Baskıdan) (Çev. Ed. S. Durmuş). Ankara: Nobel Akademik Yayınc1lık.

Yıldırım, A. ve Şimşek, H. (2011). Nitel araştırma yöntemleri. (5. Bask1). Ankara: Seçkin Yayıncılık.

Yurtbakan, E., İskenderoğlu, T. A. ve Sesli, E. (2016). Sınıf öğretmenlerinin öğrencilerin matematik dersindeki başarılarını arttırılma yolları konusundaki görüşleri. Ondokuz Mayıs Üniversitesi Eğitim Fakültesi Dergisi, 35(2), 101-119.

Yücel, Z. ve Koç, M. (2011). İlköğretim öğrencilerinin matematik dersine karşı tutumlarının başarı düzeylerini yordama gücü ile cinsiyet arasındaki ilişki. Illköğretim Online, 10(1), 133-143. 


\section{Summary}

Problem Statement: Today's training programs of countries have been developed based on the qualities of having a respected and effective curriculum at national and international level, to train each individual who is capable of representing the country at the national and international level and to support the development and protection of social and cultural values (Özdemir, 2009). Besides, highly developing world as of socio-economically, socio-culturally and politically, this situation shows that changes and developments regarding the education systems are required as well. If we look from the beginning of the Republic, there are 11 curriculum changes of mathematics course until today. The years that those stated curriculums were developed and changed determined as 1924, 1926, 1936, 1948, 1968, 1983, 1990, 1998, 2005, 2015 and 2017 (Özmantar and Öztürk, 2017). Researchers suggest that one of the most effective ways to create a good curriculum is to examine previous curricula, hence, you can establish a roadmap for the future based on your learnings from past experiences. (Özmantar, 2017, Lester, 2013; Schoenfeld, 2004.

Purpose of the Study: In this research, Bloom's curriculum evaluation based on the program's parts was taken as basis and it is aimed at evaluating by including objectives, units, educational attaintment and evaluations dimensions (Sönmez and Alacapınar, 2015) and also including program's vision and approach through comparatively examining the 2009,2015 , and 2017 Primary School's mathematics curricula. In this context, (1) is the vision presented in the 2009, 2015 and 2017 mathematics curricula? (2) Has the program approach been stated in the 2009, 2015 and 2017 mathematics curricula? (3) Are the objectives determined in the 2009, 2015 and 2017 mathematics curricula? (4) How is the content presented in 2009, 2015 and 2017 mathematics curricula? (5) Are the educational attaintment stated in the 2009, 2015 and 2017 mathematics curricula? (6) Are the evaluation dimensions stated in the 2009, 2015 and 2017 mathematics curricula? These questions have been asked. 
Method: In this study, within the context of its aim, qualitative research approach has been applied among the other research methods, and the study is a descriptive case study from qualitative research models. In the study, a teleological sampling method was applied. In this study, the data source is mathematics curricula books hence, the document examination was required. In this context, this study is a descriptive case study of qualitative research models. The data source consists of books of 2009 mathematics curricula, 2015 mathematics curricula and 2017 mathematics curricula which are approved by National Education Ministry. In this research, data analysis has been conducted via document examination method.

Findings and Discussions: As a result of this study, it is determined that 2009 mathematics curricula has a vision, on the other hand, 2015 and 2017 mathematics curricula, the vision is not included. In 2009 curriculum of mathematics course, there is a spared section for program approcah and it is stated that conceptual approach has been embraced. In 2015 and 2017 curricula, even there is no part for program's approach, unit based approach has been applied in contrast to the 2009 mathematics curricula. When the 2009, 2015 and 2017 mathematics curricula are examined, it appears that all of the three programs have a part for objectives. Apart from the programs of 2015 and 2017, in 2009 mathematics curricula there is another part was established under the title of "Objectives of Turkish National Education". When we look at 2009, 2015 and 2017 mathematics curricula, apart from 3rd grades, all grades' learning outcome have been decreased since 2009 up. While the 2009 mathematics curricula was not unit based, teachers were advised to prepare yearly plans as unit-based. In 2015 and 2017 mathematics curricula, unit-based approach has been used. It was determined that the basic skills score which was 4 in 2009, was 6 in 2015 and 9 in 2017. The 5 skills involved in the 2009 mathematics curricula remain as same in the 2015 and 2017 mathematics curricula. While the values in 2009 and 2015 mathematics curricula are not 
included, the title of values was included in 2017 mathematics curricula. It is shown that there are 7 intermediate disciplines in the 2009 mathematics curricula, however, the interdisciplinary perspective was abandoned in the 2015 and 2017 mathematics curricula. Explanations about the teaching and learning processes in the 2009 mathematics curricula were listed as in 15 items, in the 2015 mathematics curricula as 12 items and the 2017 mathematics curricula, they are listed as in 13 items. When we examine 2009 mathematics curricula, there was a specific activity example for each acquisition, in 2015 and 2017 mathematics curricula, there was no examples of activities seen. In the 2009 mathematics curricula, explanations for each acquisition and activity sample were created separately, but in the 2015 and 2017 mathematics curricula, while explanations were given for some acquisitions, at the same time, both explanations and examples of activities were provided for some acquisitions. In the 2009 mathematics curricula, a total of 144 hours for each class grade were determined and this was 180 hours for the 2015 and 2017 mathematics curricula. All of the mathematics curricula for 2009, 2015 and 2017 include the evaluation part.

Conclusions and Recommendations: In this research, Bloom's curriculum evaluation based on the program's parts was evaluated by including objectives, units, educational attaintment and evaluations dimensions and also including program's vision and approach through comparatively examining the 2009, 2015, and 2017 primary school's mathematics curricula. For a deeper study, it is suggested to further researchers which will be working on this subject, to compare all the curriculam in one dimension. 